\title{
Ethnozoological Impacts on Fauna Conservation: The Case of Chimanimani National Park
}

\author{
José Manuel Tobias Ganje ${ }^{1} \quad$ Eduardo Pinto Mulima ${ }^{2} \quad$ Luís Cristóvão $^{1}$ \\ 1.Faculty of Environmental Engineering and Natural Resources, Zambeze University, Mozambique \\ 2.Agricultural Research Institute of Mozambique, Centre Zonal Centre, Mozambique
}

\begin{abstract}
Interactions between humans and fauna have been considered essential to better understand the dynamics of socio-ecological systems. This study aimed to assess the ethno-zoological impact on fauna conservation in Chimanimani National Park, by studying the Mpunga Centro community values applied in the use of fauna species, their participation in conservation and the mensuration of ethnozoological impacts. Methodologically, bibliographic review was used for theoretical support and the data collection in the field for information analysis in a sample of 82 households. The collected data were processed on SPSS statistical package, version 20.0 and analyzed at a level of significance of $5 \%$. The results showed that the community ecologically valorizes the species, on traditional medicine, on educational and recreational, cultural and religious value. The results also showed that the community participates in conservation through preventing uncontrolled fires, getting involved in conservation agriculture, beekeeping, community inspection and ecotourism. Having concluded that the traditional knowledge of Mpunga Centro Community on the use of local fauna, influences on wildlife conservation of the Chimanimani National Park.
\end{abstract}

Keywords: Ethnozoology, conservation, local community, fauna species, Chimanimani National Park

DOI: $10.7176 / J R D M / 76-02$

Publication date:June $30^{\text {th }} 2021$

\section{INTRODUCTION}

The animal and human connection is a relationship of thousands of years and the use of fauna resources constitutes an important cultural element of human populations worldwide (Barbosa et al., 2014). Mozambique has more than 4,200 species of animals, including 3,075 insects, 726 birds, 214 mammals, 171 reptiles and 85 amphibians in fauna biodiversity. Therefore, it is evident that as indicated, by main species, they reflect more for Elephants (30,000), Buffaloes (200,000), Wildebeest (35,000), Zebras (35,000), Waterbuck (70,000), Hippos $(15,000)$, Sable antelope $(30,000)$, Antelopes $(200,000)$ (MICOA, 2007). Consequently, Mozambique has bet on conservation measures (SDG 15), mainly in-situ, which is demonstrated by the fact that $26 \%$ of the national territory is covered by Conservation Areas (CAs), 13 of which are terrestrial and 2 marines. In the last few years, 3 National Reserves have been elevated to National Park and several brave and community farms (MITADER, 2015). However, the current situation of CAs reveals the need for a general review of the current state of biodiversity in these areas.

Currently, the concern with the conservation of biological diversity has been growing mainly, with regard to the degradation of the environment and unsustainable practices in the use of natural resources. However, the great challenge is to reconcile the conservation of natural resources, with human needs, mainly for local communities, which depend directly on natural resources for their needs (Arruda, 1999). Nevertheless, it is inconceivable to design conservation strategies without considering the human element and the impacts arising from the use of natural resources. In this context, ethnozoology is dedicated to investigate the regional uses of animals, contributing for the fauna species to be properly valued not only from an ecological point of view, but also from an economic and social point of view. Therefore, it seeks discussions with local communities and points out ways based on traditional knowledge to provide subsidies to implement the conservation of species, based on a social reality (Alves and Souto, 2011). Also, ethnozoology proposes a new conservation model, which includes the rescue, study and enhancement of local ecological knowledge, which results in sustainable managements that are much more adapted to local conditions and with greater chances of success (Lima et al., 2014).

New opportunities and threats for the conservation of biodiversity have emerged with the country's economic development. There is a growing pressure on existing resources due to the increase in economic activities and demographic growth, with environmental impacts, namely on climate change (SDG 13), on the extinction of species and rare ecosystems. This study, therefore, intends to study the ethno-zoological impacts on fauna conservation, in the Chimanimani National Park, specifically in the community of Mpunga Centro, Sussundenga district, Manica Province.

\section{MATERIAL AND METHODS}

The present study was conducted in the Province of Manica, District of Sussundenga, Community of Mpunga 
Centro, in the National Park of Chimanimani (NPC). The data collection guide (Table 1) was composed of dependent and independent variables according to Lakatos and Marconi (2003).

Table 1: Dependent and independent variables of the study

\begin{tabular}{|c|c|c|}
\hline $\begin{array}{l}\text { Dependent variables } \\
\text { (Y) }\end{array}$ & Independent variables $(\mathrm{X})$ & Methods \\
\hline \multirow{2}{*}{$\begin{array}{l}\text { Values of fauna use by } \\
\text { local communities }\end{array}$} & Recreation, ecological balance, preservation, clothing, cosmetics & $\begin{array}{l}\text { Unsystematic } \\
\text { observation }\end{array}$ \\
\hline & $\begin{array}{l}\text { Food, medicine, education, research, culture, trade, animal } \\
\text { traction }\end{array}$ & $\begin{array}{l}\text { Semi structured } \\
\text { interview }\end{array}$ \\
\hline \multirow{2}{*}{$\begin{array}{l}\text { Participation in wildlife } \\
\text { conservation }\end{array}$} & $\begin{array}{l}\text { Local communities, local authorities, associations, the private } \\
\text { sector, NGOs }\end{array}$ & $\begin{array}{l}\text { Semi structured } \\
\text { interview }\end{array}$ \\
\hline & Government, cooperation partners and international community & $\begin{array}{l}\text { Literature } \\
\text { review/ debates }\end{array}$ \\
\hline $\begin{array}{l}\text { Ethnozoological } \\
\text { impacts on wildlife } \\
\text { conservation }\end{array}$ & $\begin{array}{l}\text { - Traditional knowledge about the use of local fauna; } \\
\text { - Valuation of traditional knowledge on the part of the } \\
\text { management entity in contributing to the maintenance } \\
\text { of local fauna; } \\
\text { - } \quad \text { Relationship between fauna and the local community; } \\
\text { - Man and wildlife conflict mitigation techniques used by } \\
\text { the community; } \\
\text { - Advantages and disadvantages of traditional knowledge } \\
\text { for wildlife conservation. }\end{array}$ & Questionnaire \\
\hline
\end{tabular}

The NPC consists of 4 communities, in which there are a total of 2530 households. Of these, the Community of Mpunga has a total of 817 households (INE, 2017). For determination the sample size the method of Case (1990) was used, resulting in a sample of 82 households.

For data collection, the "Kobotoolbox" tool was used, which allows data collection in the field using smartphones or tablets, as well as with paper or computers (Schmied, 2018). The questionnaires were prepared in Excel XLS following a standardized "programming language". For data processing and analysis, responses were first selected and standardized, followed by coding and tabulation. Statistical analysis was performed using the IBM SPSS Statistics 20 statistical package, where analysis of variance (ANOVA) was performed and comparison of means using the Tukey test at $5 \%$ confidence interval.

As for the characterization of the interviewees, there was $18 \%$ female and $82 \%$ male. Of this number, $18 \%$ corresponded to the age group between $18-25$ years old, $40 \%$ corresponded to the age group between $25-35$ years old, $35 \%$ between $35-65$ years old and $6 \%$ over the age of 65 years old.

\subsection{RESULTS AND DISCUSSION}

3.1 Values of the use of fauna species by the community of Mpunga Centro

For ecological values and their use, it was noted from interviews that animals are elements of the food chain among tertiary, secondary and primary consumers (47\%). In addition to the food chain, animals are responsible for the dissemination of seeds through consumption and excretion $(21 \%)$ and others as good indicators of water quality $(15 \%)$. Additionally, it was noted that birds help pollinate plants while wild animals are used for vegetative control of crops $(2 \%)$. Also, it was observed that the fauna species are fundamental elements in ecological quality, since they guarantee plant control, their dissemination, participation in the food chain as well as in the indication of the level of water contamination. Other studies have reported that wildlife species facilitate the achievement of an ecologically balanced environment and the consequent healthy quality of life (Bechara, 2003 and Abdalla, 2007). These species, along with other factors, maintain the harmonious functioning of the ecosystem, coupled with the aspect of detecting biotic and abiotic elements. In addition to these values, the interviewees indicated that faunal species have values in traditional medicine, where they use elephant excreta to treat various diseases (stomach pains) or to ease labor pains. Spine pains are treated by ancient healers in the region using a boa constrictor's tail while parts of the crocodile are used to cure various diseases, but their slaughter or use of parts of this animal must be authorized by local authorities due to the existence of substances harmful to human health (Figure 1). 


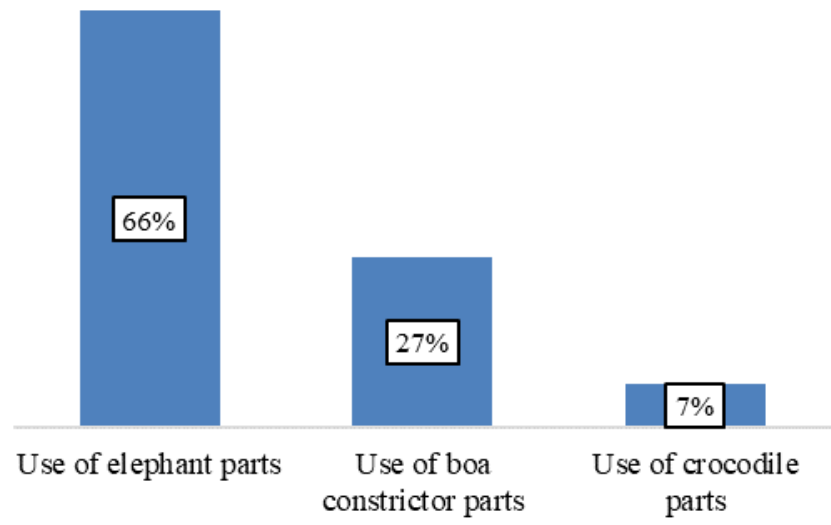

Figure 1: Value in traditional medicine

According to Fiorillo (2003) and Abdalla (2007), fauna species play a major role in obtaining discoveries of new substances and technologies for treating diseases in humans. There are other experiments carried out by the pharmaceutical industry for the production of antihypertensive and anti-cancer drugs using snake venom and creation of the insulin produced in the beta cells of the islets of Langerhans, endocrine pancreas of mammals (bovine) and anti-ophidic serum obtained from antibodies of horse blood.

Regarding the pedagogical and recreational value, two variables were evaluated, environmental education and study of elephant behavior, where $90 \%$ of respondents are aware that environmental education is the instrument that makes the community aware of the value that wild animals have for the community and the rest $10 \%$ study the behavior of elephants in order to avoid possible conflicts between man and wildlife.

In terms of cultural value, the species were categorized into two degrees of importance, the first being tribal identification (61\%) and the second use for traditional ceremonies (39\%). In the first, the species are used during the transmission of traditional practices from the oldest to the youngest through the use of species of monkeys, porcupine, crocodiles, elephants, boa constrictors, known locally as mutupo (totems). The second category is recognized simply for traditional ceremonies. This phenomenon is typical in the African continent because the fauna species constitute totem or symbol of ancestors. Asare et al. (2014) argued that many tribes and clans in Africa recognize certain animals as totems, that is, guardian spirits and helpers, being obliged not to kill, eat or destroy.

\subsection{Community participation in the conservation of fauna in the park}

The results found that the majority of the community with the knowledge have participated in the conservation of fauna through the practice of actions against uncontrolled fires while others avoid destroying species habitats through the non-opening of new farms. Additionally, part of the community avoids poaching and others avoids contaminating water courses (Figure 2).

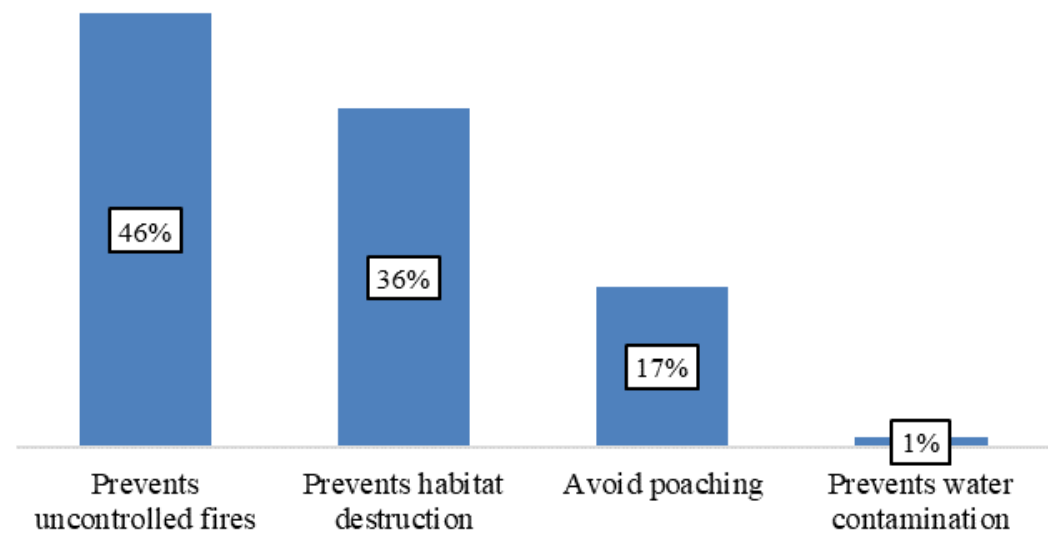

Figure 2: Individual participation in wildlife conservation

The results obtained show that the Community of Mpunga participates actively in the conservation of fauna species through the Natural Resources Management Committee (CGRN) which supports the inspection, application of traditional knowledge, practices and cultures. This type of participation in wildlife conservation is considered to be functional as advocated by Pimbert and Pretty (2000). On the other hand, the community is 
involved in conservation agriculture projects (37\%), beekeeping (26\%), community surveillance $(28 \%)$ and ecotourism activities (9\%) within the park. The community's involvement in the projects is done as a source of information or manpower in project activities in exchange for essential products, $69 \%$ of which are for information extraction and $31 \%$ for material incentives.

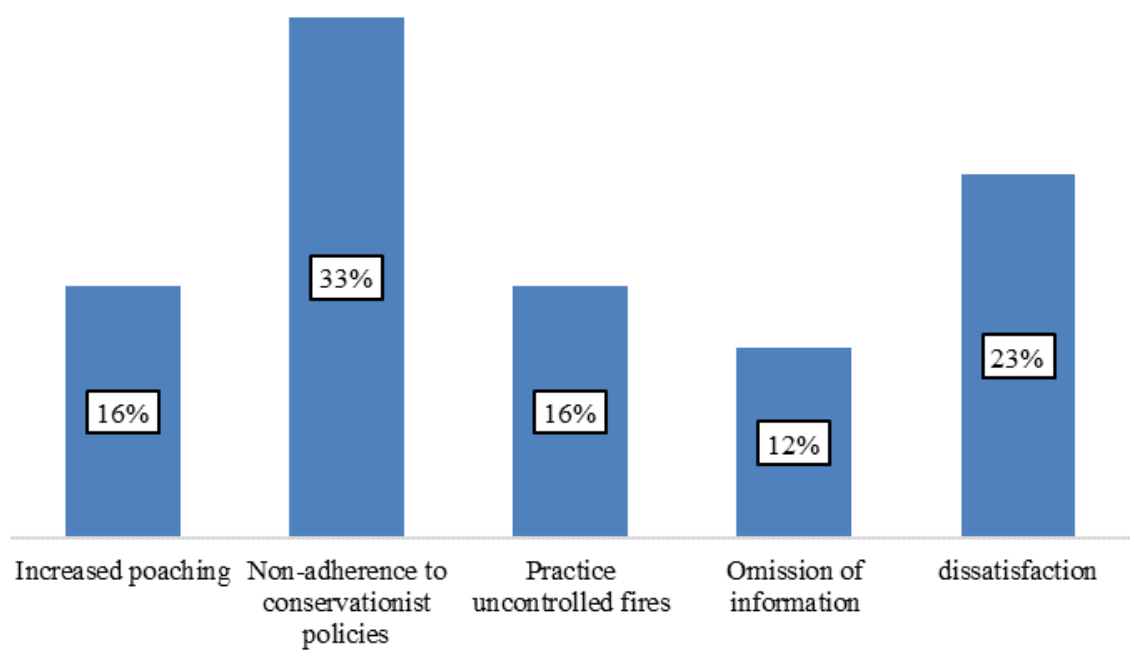

Figure 3: Possible if they are excluded from participating in conservation projects

The weak involvement of community members in the park's projects discourages the adherence of conservation policies, control of uncontrolled fires, omission of information and an increase in poachers, Figure 3.

The motivational relationship for the community to conserve fauna has to do with the values, knowledge and perceptions that it has for the development of an interdependent relationship (Drew, 2005 and Alves et al., 2009).

\subsection{Ethnozological impacts in relation to fauna conservation in the park}

The results showed that the community has knowledge about the fauna and its use, with $38 \%$ of the interviewees not slaughtering animals indiscriminately, $35 \%$ respecting the hunting rules because the animals are controlled by the inspectors and $27 \%$ referred to the hunting ban community leaders. The knowledge of the rules for the conservation of fauna by members is mostly obtained in stories about the area's ancestors and prophecies, in family gatherings, local leaders and in church ceremonies. It is important to emphasize that this knowledge is transmitted orally, and there is a need to document these historical facts due to the weak dissemination within the community, mainly due to the small number of elderly people. Also, the data showed that $36 \%$ of respondents take good advantage of traditional knowledge through environmental conservation awareness that they have acquired over the years, $31 \%$ promote conservation actions for other communities that do not conserve fauna, $19 \%$ guarantee that there is a significant increase in community participation in the management of wildlife resources, and $15 \%$ believe that well-managed traditional knowledge for the benefit of the community, there will be preservation of cultural authenticity.

In ecological relations between the community and wild animals, the results showed that elephants have a greater impact, as they invade farms and sometimes residences, sometimes attack people or domestic animals in the dispute for food or invasion of a locality in the areas rural areas (Figure 4).

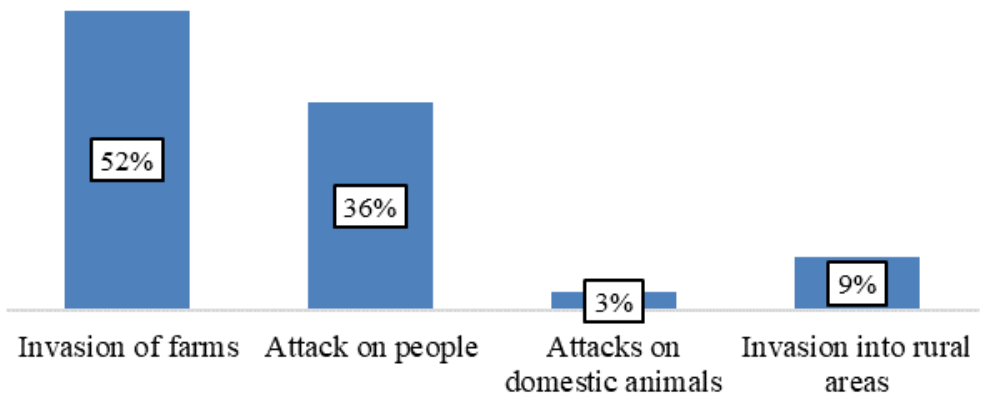

Figure 4: Reasons for the disharmonious relationship between the community and wild animals 
The existing relationship is more disharmonious than harmonic, as there is a negative interaction between the community and wild animals. This idea is defended by Cerqueira and Ferreira (2017) when referring to the disadvantages in living together due to the constant invasion of elephants and other animals to the fields, rural areas and the attack on people and domestic animals. For prevention, the community has adopted rudimentary and modern techniques to chase away problematic animals such as the use of fence in the fields (less effective), use of light signals and emission of acoustic sounds (more effective). Community members (54\%) hate having elephants around because they invade farms and homes. Other members $(21 \%)$, loathe snakes because some are poisonous while the opinion of others $(10 \%)$ is in relation to monkeys that they consider bold when invading homes in search of food. Also, there have been opinions of loathing crocodiles (4\%) and owls (2\%).

\subsection{CONCLUSION}

Based on the results obtained in the community of Mpunga Centro - Chimanimani National Park, the following conclusions can be reached:

- Six values of the use of fauna species were identified, namely: ecological, traditional medicine, educational and recreational, cultural and religious. It was found that in ecological values animals participate in the food chain; in traditional medicine the community animal components to treat various diseases; in the pedagogical and recreational value, the community is aware that environmental education is the instrument that makes the value of animals aware in the community; in culture, tribal identification is the cultural value that most identifies the community, since some members of the community claim that monkeys are sacred to their families; in religion they use fauna species to invoke their ancestors when there are serious problems in the community, in other values the community feeds on meat of small game.

- It was observed that the community individually participate in the prevention of uncontrolled fires, and collectively through the Natural Resources Management Committee, where the community is involved in conservation agriculture, beekeeping projects, community inspection and ecotourism. Also, deep discontent is noted when the community is excluded from the projects.

- In terms of ethno-zoological impacts regarding the conservation of fauna, it was noted that the community has respected the fauna and its use. Also, it was observed that traditional knowledge has the advantage of providing environmental conservation awareness to the community and has the disadvantage of distorting and adapting knowledge related to fauna.

\subsection{ACKNOWLEDGEMENTS}

The authors express their gratitude to the Ministry for Foreign Affairs in Finland for providing financial support through the Sustainable Management of Natural Resources in Mozambique (SuMNatuRe) project.

\subsection{REFERENCES}

1. Abdalla, A. (2007). A proteção da Fauna e o tráfico de animais silvestres. Piracicaba, São Paulo: UNIMEP.

2. Alves, R., Barbosa, J., Souto, W., \& Barboza, R. (2009). Animal-based Remedies as Complementary Medicines in the Semi-arid Region of Northeastern Brazil. eCAM.

3. Alves, R.R.N. e Souto, W.M.S. (2011). Ethnozoology in Brazil: current status and perspectives. London: Journal of Ethnobiology and Ethnomedicine 7 (22): 1-18.

4. Arruda, R. (2000). "Populações Tradicionais" e a proteção dos recursos naturais em unidades de conservação. São Paulo: HUCITEC.

5. Asare, T., Howard, E., e Peligah, Y. (2014)."The Socio-Cultural Significance of Akan Totemsin Textile Designs: A Means for Preservation of Wildlife in Ghana", The International Journal of Science and Technoledge. Vol. 2. №. 6. pp. 155

6. Barbosa, E., Mariano, E., \& Chaves, M. (2014). Aspectos etnozoológicos da avifauna do município de Jaçanã, Rio Grande do Norte e possíveis factores de ameaça na região. Recife: Revista Nordestina de Zoologia.

7. Bechara, E. (2003). A proteção da fauna sob a óptica constitucional. São Paulo: Editora Juarez de Oliveira.

8. Drews, C. (2002). Attitudes, knowledge and wild animals as pets in Costa Rica.Costa Rica: Anthrozoös.

9. Drew, J. A. (2005). Use of Traditional Ecological Knowledge in Marine Conservation. Malden USA: Conservation Biology 19: 1286-1293.

10. Ferreira, L.C. (2017). Spatial ecology of a top-order marine predator, the tiger shark (Galeocerdo cuvier). Pernambuco: Universidade Federal do Rio Grande do Sul. Retrieved: https://doi.org/10.4225/23/593f61c4257bf. on 20 April of 2021.

11. Fiorillo, C. (2003). Curso de direito ambiental brasileiro (4 ed.). São Paulo: Saraiva.

12. Instituto Nacional de Estatística - INE. (2017). Censo 2017: IV Recenseamento Geral da População e Habitação. Maputo, Moçambique. 95 p. available online: www.ine.gov.mz.: 28 July of 2020.

13. Lakatos, E., \& Marconi, A. (2003). Fundamentos de metodologia científica (5 ed.). São Paulo: Atlas.

14. Lima, J., Florêncio, R., \& Santos, C. (2014). Contribuições da Etnozoologia para a Conservação da Fauna 
Silvestre (Vol. 4). Revista OURICURI.

15. Ministério da Terra, Ambiente e Desenvolvimento Rural - MITADER. (2015). Estratégia e Plano de Acção para a Conservação da Diversidade Biológica em Moçambique (2015-2035). Maputo.

16. Ministério Para a Coordenação da Acção Ambiental - MICOA. (2007). Estratégia Ambiental para o Desenvolvimento Sustentável de Moçambique. Maputo.

17. Pimbert, M., \& Pretty, J. (2000). Parques, comunidades e profissionais: incluindo "participação" no manejo de áreas protegidas.São Paulo: UCITEC.

18. Schmied, P. (2018). Guia Rápido para Recolha de Dados com Telemóveis. People in Need. IndiKit. 2p. 